\title{
An Empirical Investigation of the Impact of Customer Learning on Customer Experience in the Context of Knowledge Product Use
}

\author{
Yong Jin KIM ${ }^{1}$, Myung-Seong YIM ${ }^{2}$
}

Received: September 10, 2020 Revised: November 08, 2020 Accepted: November 16, 2020

\begin{abstract}
The role of customers has changed from that of passive users to value co-creators. Therefore, it is important to understand how customer learning takes place and how it affects customer experiences with services and products. However, while past studies insist on the importance of the issues in designing customer experiences, they do not empirically address these issues. This study investigates the support processes for customer learning, and their impact on customer learning, which in turn influences customer experience. To test the hypotheses, we employed the survey method. Target informants were the actual users of Apple iPods. A total of 200 survey questionnaires were distributed and 146 were collected. Among these, seven erroneous responses were excluded, leaving 139 usable ones. The proposed model was empirically analyzed using the Covariance-based SEM (Structural Equation Modelling) technique. The findings of this study suggest that, among the three support processes in customer learning, learning-by-doing support and learning-by-investment support positively affect customer learning, which influences customer experience. This study contributes to the literature by identifying different types of support for different kinds of customer learning processes and by empirically testing the impact of the support for the process on customer learning, and in turn, its impact on customer experience.
\end{abstract}

Keywords: Customer Experience, Knowledge Management, Customer Learning Process, Knowledge Product, Service Innovation

JEL Classification Code: M10, M15, O30, O31, O33

\section{Introduction}

With advancements in the service industry, the reliance of industries, including manufacturing, on services increases. Globally, the proportion of the service industry in the GDP is greater than $64.9 \%$ (World Bank, 2018). Recognizing the importance of services as a new growth engine, companies, including IBM and GE, have transformed their businesses into service-oriented ones, and suggested a new discipline, called "services science," which is believed to be multi-disciplinary in nature (Glushko, 2008). Services science suggests that services need to be measured and designed in a scientific way

${ }^{1}$ First Author. Professor, Department, Sogang Business School, Sogang University, Seoul, Korea [Postal Address: 35 Baekbeom-ro, Daeheungdong, Mapo-gu, Seoul, Korea] Email: yongjkim@sogang.ac.kr

${ }^{2}$ Corresponding Author. Associate Professor, Department of Business Administration, Sahmyook University, Seoul Korea [Postal Address: 815 Hwarang-ro, Nowon-gu, Seoul, 01795, Korea] Email: msyim@syu.ac.kr

(c) Copyright: The Author(s)

This is an Open Access article distributed under the terms of the Creative Commons Attribution Non-Commercial License (https://creativecommons.org/licenses/by-nc/4.0/) which permits unrestricted non-commercial use, distribution, and reproduction in any medium, provided the original work is properly cited. and continuously improved by relying on different kinds of knowledge, including management, engineering, mathematics, and cognitive science. These activities cannot focus only on the production and consumption of services, but must address the entire process of value creation in the service, from design to production to maintenance and improvement (Alter, 2008; Gronroos, 1990; Kim \& Nam, 2007).

Recently, Vargo and Lusch (2004) suggest the term "service-dominant logic" as opposed to "product-dominant logic" where value cannot be created by service providers. Instead, it can be created only through the interaction between customers and service providers and customers play the role of co-creators of value. In this framework, customers are not passive users anymore, but are active creators of value who participate in a variety of value creation activities from service design to production, from operation and maintenance to evaluation (Vargo \& Lusch, 2004, 2006). What Vargo and Lusch (2004) and other researchers have missed is the question of how customers attain the capability to express their concerns around and knowledge of the services they want to have, properly. In this study, we define this as customers learning about purchasing, applying, and managing services and products pertinent to their needs, which allows them to gain knowledge and skills 
to maximize the value of services and products that they have. Thus, customer learning is critical for customers to make the best use of services and products and to create the value expected when they make their purchases (Hindasah \& Nuryakin, 2020; Song, Chang, \& Chang, 2018; Wang \& Lam, 2019).

While customers need to develop necessary skills and knowledge to use the services and products, service providers need to support customer learning processes pertinent to customers' capability so that they can communicate with customers in an efficient manner (Payne, Storbacka, \& Frow, 2008). Various kinds of support for customer learning processes affect the performance of customer learning, which, in turn, influences the attitudes toward service use, preferences, and eventually, customer experience with the service, resulting in enhanced interaction with customers and thus, more revenue for companies (Payne et al., 2008). Customer learning takes place not only between customers and companies, but also among customers with customer communities where nonlinear and complex interactions take place. Including this mode of customer learning actively is very important to maximize customer experience (Nam, Kim, Nam, Pae, \& Byun, 2008).

As discussed above, past studies agree to the fact that support for customer learning either directly through companies' resources, or indirectly through partners' resources and customer communities, is critical for value co-creation by companies and customers (Vargo \& Lusch, 2004; Payne et al., 2008). However, to the best of our knowledge, there is little research on the issues of how customers learn, what the processes are, and how these factors are interrelated to affect customer experience. In this study, we take three customer learning processes (learning-by-doing, learning-by-investment, and learning-from-others) from Ryu, Kim, Chaudhury, and Rao (2005) and investigate the impact of the support for the processes on the experience of Apple iPod users.

\section{Theoretical Background}

\subsection{Service-Dominant Logic}

Past studies have examined the change in the economic paradigm from a product-based economy to a service based one. Pine (1993) argues that customization to meet individual customer requirements rather than mass-production is important to gain competitive advantage in the market. Prahalad and Ramaswamy (2000) suggest that value creation takes place not from the exchange of the products and services itself, but from the use of the products and services by customers. Pine and Gilmore (1999) insist that the focus of business is on customer experience with the product and service rather than consumption or purchase of the product or service.
Based on past studies regarding the change in the economic structure toward high service reliance, Vargo and Lusch (2004) define the new economy as one that follows service-dominant logic in contrast with the traditional one based on product-dominant logic. The basic premise of the service-dominant logic is that value is created in the form of "value-in-use" and not "value-in-exchange" (Nam et al., 2008). That is, value for customers is created through active interactions between service providers and customers and not through the unilateral provision of products and services by companies. Accordingly, in this framework, customers are considered value co-creators and the role of customers as value co-creators and their participation in service provision are critical for successful value creation (Vargo \& Lusch, 2006). As such, in the framework of service-dominant logic, the primary determinant of value is customer experience that can be accumulated over time throughout interaction between customers and service providers, and the use of products and services (Payne et al., 2008).

\subsection{Customer Learning}

Customers as value co-creators may want to obtain knowledge and skills enough to satisfy their needs in using services and products, which requires effective learning about the services and products and their use. Customer learning takes place through self-learning processes or supported learning processes by service providers, resulting in a variety of knowledge and skills pertinent to the services and products that they want to use (Vargo \& Lusch, 2004; Payne et al., 2008). The accumulation of knowledge and skills provides customers with absorptive capacity that allows customers to have rich experiences in using service and products (Cohen \& Levinthal, 1990).

If companies support customer learning processes in a systematic and effective manner, customers can utilize services and products in a more diverse and useful way which in turn will lead to the maximization of their experience with the service and product. Positive customer experience with the service and product is known to induce behavior such as re-purchase and positive word-of-mouth exchange of knowledge (Payne et al., 2008). Accordingly, understanding when, where, and how customer learning takes place is necessary to achieve the objective of value co-creation.

Ryu et al. (2005) identify individual learning process for knowledge acquisition into learning-by-doing, learning-byinvestment, and learning-from-others. This categorization of individual learning is very comprehensive and includes all three processes, which are separately investigated by past studies. In this study, following the categorization of Ryu et al. (2005), we define the support for customer learning processes provided by service providers, into the same three categories. 
First, service users accumulate specialized knowledge by using services and products. In particular, it is known as learning-by-using, which leads to an improvement in, and thus, increased use of a service or product (Rosenberg, 1983). This type of learning where users attain more knowledge and skills pertinent to the use of the service and product through more use is defined as learning-by-doing. By supporting this process, service providers help individuals accumulate specialized and in-depth knowledge on the service and product (Ryu et al., 2005).

Secondly, customers tend to invest their time and money to improve their knowledge and skills to use the product and service at hand better. Obtaining knowledge and skills to use, in particular, new services and products, requires the investment of resources and time on the part of individuals. This process is defined as learning-by-investment that allows individuals to have a wider range of knowledge and skills to use the services and products in a variety of ways (Ryu et al., 2005). Providing support for this process is imperative for service providers, because they can implement various marketing tools, such as cross selling and up selling when customers have comprehensive knowledge on their products and services (Ryu et al., 2005).

Thirdly, customers obtain knowledge about and skills relating to services and products of their interest while exchanging knowledge with other customers within customer communities. The knowledge acquired through this exchange with other customers can be integrated into their existing body of knowledge. This type of learning is defined as learning-from-others. Companies have recently started supporting this process of knowledge acquisition by actively involving customers on their websites (Ryu et al., 2005). With advancements in the internet, the exchange of knowledge and information through customer communities is called the electronic word-of-mouth exchange (HennigThurau, Gwinner, Walsh, \& Gremler, 2004). Electronic word-of-mouth exchange, like the traditional word-of-mouth exchange, is considered to affect the purchase decision of customers to a greater extent than marketer-created sources of information on the internet, because it is perceived as more credible, empathetic, and relevant by customers (Bickart \& Schindler, 2001; Richins \& Root-Shaffer, 1988).

\subsection{Customer Experience}

As customers use services and products, they experience the value proposed (Alter, 2008). Accordingly, it is necessary for service providers to understand customer experience from a customer's perspective, and not from a service provider's perspective. Gentile, Spiller, and Noci (2007) define customer experience as the experience with the environment and the relationship between customers and service providers. Customer experience occurs within a very complex interaction environment between customers and a product/service, service providers and a part of the service providers (LaSalle \& Britton, 2003; Shaw \& Ivens, 2005; Ramaswamy, 2006). Customer experience depends on according to time, place, and the context that a customer is in. It plays an important role in creating value (Nam et al., 2008).

Figure 1 illustrates a general framework for customer experience. In this framework, service providers offer value proposition, and customers perceive the value offered through interactions with service providers and use of the services and products. Customers expect value and eventually actualize the value through the use of the service or product (Gentile et al., 2007).

\section{Research Model and Hypothesis}

This study assumes that customer learning is affected by support for the three learning processes, and positively influences customer experience with services and products. Figure 2 illustrates the proposed research model.

As discussed in the previous sections, customer experience takes places within a very complex interaction environment and leads to value maximization (LaSalle \& Britton, 2003; Shaw \& Ivens, 2005; Ramaswamy, 2006). It is affected by customer learning (Payne et al., 2008). In particular, in the case of knowledge products and the service use environment, customer learning is critical to the maximization of customer experience and subsequently that of the performance of companies. In this study, we take Apple's iPod, which provides services including playing music and videos, as an example of a knowledge product.

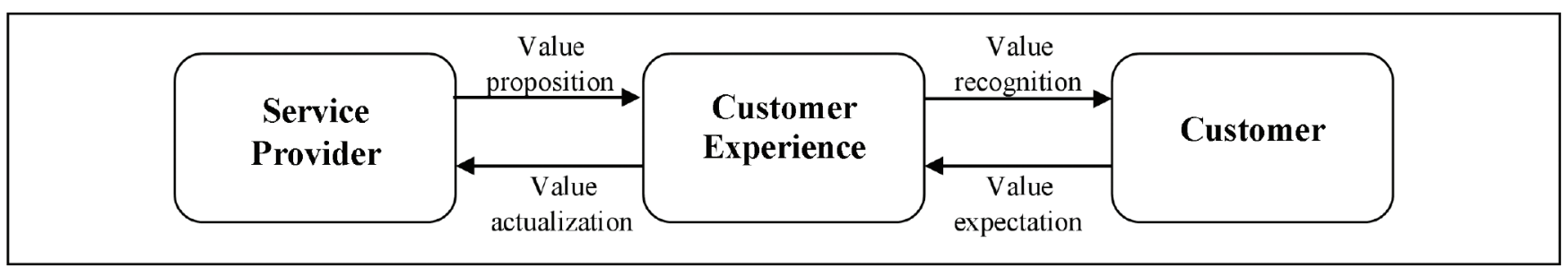

Figure 1: Customer Experience Framework 


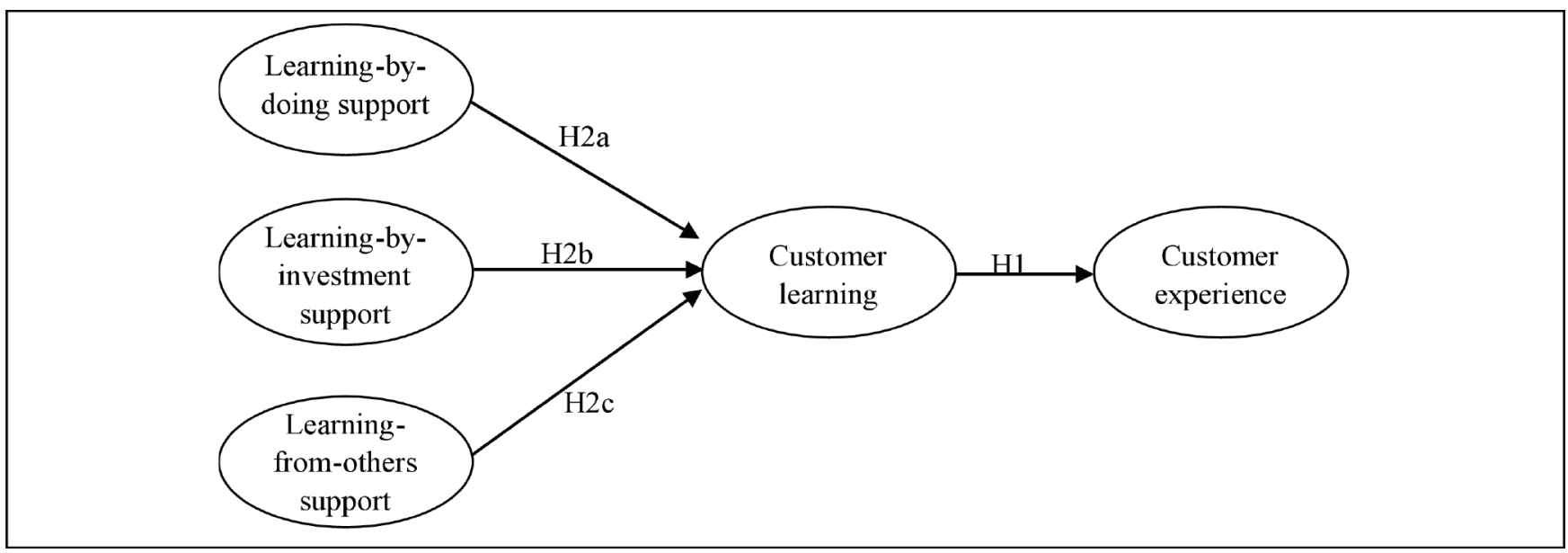

Figure 2: The Proposed Research Model

A knowledge product is regarded as a high-tech product that enjoys increasing returns to scale through learning-by-using (Rosenberg, 1983) and the network effect (Shapiro \& Varian, 1999). A knowledge product can offer richer experiences to customers when they have in-depth knowledge of the product and service. Based on the above discussion, hypothesis 1 can be proposed as follows.

\section{H1: Customer learning positively affects customer} experience.

Customer learning is referred to as the process through which customers acquire knowledge about a service or product and its usage by using the service and product (Payne et al., 2008). Ryu et al. (2005) identify the learning process used in acquiring knowledge in learning-by-doing, learning-by-investment, and learning-from-others. We develop hypotheses based on the support for the processes in the context of the use of iPods.

First, the learning-by-doing process involves knowledge and skills through which customers can download and install a variety of applications that run on an iPod. There are a lot of beta versions of knowledge products and services on the internet that are being used for free of charge. This is primarily because learningby-using is believed to create increasing returns to scale along with the network effect (Shapiro \& Varian, 1999). In particular, free download and experience is important for customers to understand the service or product. Accordingly, the support for customers to directly use and experiment with it before or after they purchase it significantly affects customer learning.

H2a: Support for the learning-by-doing process positively affects customer learning.
Secondly, learning-by-investment is the process where customers obtain manuals and magazines provided by Apple for its iPod, and then study them to use the product appropriately. While the purpose of support for the learning-by-doing process is to help customers gain a better understanding of the service or product by allowing direct experience, learning-by-investment support is aimed at helping customers indirectly learn about the functions and performance of the service or product by investing their time and effort in accessing relevant materials (Ryu et al., 2005).

Therefore, proper support for the learning-by-investment process allows customers to understand the functions of the service and product and then compare them with other services to acquire the remaining knowledge of it. Equipped with proper knowledge, customers can find a better way of utilizing the service and product.

H2b: Support for the learning-by-investment process positively affects customer learning.

Finally, the learning-from-other process involves the accumulation of knowledge on the usage of the Apple iPod through the exchange of knowledge and information with other customers. In fact, many companies put in a lot of effort to build active customer communities, because the impact of the knowledge acquired from peer customers or colleagues is greater than that of the information provided by service providers (Bickart \& Schindler, 2001). In addition, customer communities play an important role in improving the functionality of a service or product through comprehensive discussions and solutions developed during the discussions (Prahalad \& Ramaswamy, 2003), which lead to positive word-of-mouth exchanges (Bickart \& Schindler, 2001). Accordingly, for companies, fostering communication among customers positively influences customer learning. 
H2c: Support for the learning-from-others process positively affects customer learning.

\section{Research Methodology}

\subsection{Data Collection}

To test the hypotheses, we employed the survey method. We developed a survey questionnaire, modifying items from previous studies and wherever necessary, creating new items. The survey was administered using both, paper-based and web-based questionnaires. To avoid errors involving a web-based survey, we designed the web-based questionnaire to include response time and IP addresses. Where the same IP address or sequence in response time was found, the response was excluded from the analysis.

Target informants were the actual users of Apple iPods. A total of 200 survey questionnaires were distributed and 146 were collected. Among these, seven erroneous responses were excluded, leaving 139 usable ones. Table I shows the demographic information of the respondents.

\subsection{Measurement Model Test: Reliability and Validity}

To test the reliability and validity, we used the Exploratory Factor Analysis (EFA) using SPSS version 16 for Windows. We employed principal component analysis with varimax rotation method. Varimax rotation relies on orthogonal rotation so that it can clarify the relationship between observed variables and factors and make interpretation easier (Lim, 1996). In an exploratory study, loadings greater than 0.4 are regarded as significant, and those greater than 0.5 are considered very significant (Chae, 2004). All loadings in this study are greater than 0.5 . To test internal reliability, we used Cronbach's $\alpha$. All values for construct level $\alpha$ are greater than 0.6 , meeting the cut-off criterion (Chae, 2004).

Table 1: Demographic information

\begin{tabular}{|l|l|c|c|}
\hline \multicolumn{2}{|l|}{ Categories } & Frequency & Ratio (\%) \\
\hline \multirow{4}{*}{ Age } & Less than 20 & 7 & $5 \%$ \\
& $20-30$ & 97 & $70 \%$ \\
& $31-40$ & 32 & $23 \%$ \\
& Greater than & 3 & $2 \%$ \\
\hline \multirow{3}{*}{ Gender } & 40 & 81 & $58 \%$ \\
& Male & 58 & $42 \%$ \\
\hline \multirow{3}{*}{ Occupation } & Female & 85 & $61 \%$ \\
& Student & 48 & $35 \%$ \\
& Employee & 6 & $4 \%$ \\
\hline Total & others & 139 & $100 \%$ \\
\hline
\end{tabular}

Finally, convergent and discriminant validity are assessed by checking that the AVE of each construct is larger than its correlation with the other constructs, and that each item has a higher loading on its assigned construct than on other constructs (Fornell \& Larcker, 1981). Although AVE values need to be greater than 0.5 to secure convergent validity (Fornell \& Larcker, 1981), AVE values for our newly developed constructs are less than the cutoff value. However, considering the exploratory nature of this study, we accepted the values greater than 0.4 as adequate for further analysis. Table 3 shows the square root of the AVE of each latent variable and the correlations of all variables. The diagonal elements are correlations of each construct with its own measurement items, which is the square root of AVE. Off-diagonal elements are the correlations between constructs. Each construct is more highly correlated with its own measures than with any other constructs. This indicates that strong discriminant validity exists among the constructs.

Table 2: EFA Results

\begin{tabular}{|c|c|c|c|c|c|c|}
\hline \multirow{2}{*}{ Constructs } & \multirow{2}{*}{ Items } & \multicolumn{5}{|c|}{ Constructs } \\
\hline & & 1 & 2 & 3 & 4 & 5 \\
\hline \multirow{3}{*}{$\begin{array}{l}\text { Learning-by- } \\
\text { Doing Support }\end{array}$} & LD1 & .534 & & & & \\
\hline & LD2 & .711 & & & & \\
\hline & LD3 & .752 & & & & \\
\hline \multirow{3}{*}{$\begin{array}{l}\text { Learning-from- } \\
\text { others Support }\end{array}$} & LO1 & & .545 & & & \\
\hline & LO2 & & .830 & & & \\
\hline & LO3 & & .577 & & & \\
\hline \multirow{4}{*}{$\begin{array}{l}\text { Learning-by- } \\
\text { investment } \\
\text { Support }\end{array}$} & LI1 & & & .742 & & \\
\hline & LI2 & & & .799 & & \\
\hline & LI3 & & & .685 & & \\
\hline & LI4 & & & .536 & & \\
\hline \multirow{4}{*}{$\begin{array}{l}\text { Customer } \\
\text { Learning }\end{array}$} & L1 & & & & .857 & \\
\hline & L2 & & & & .815 & \\
\hline & L3 & & & & .778 & \\
\hline & L4 & & & & .778 & \\
\hline \multirow{3}{*}{$\begin{array}{l}\text { Customer } \\
\text { Experience }\end{array}$} & EX1 & & & & & .864 \\
\hline & EX2 & & & & & .891 \\
\hline & EX3 & & & & & .891 \\
\hline \multicolumn{2}{|l|}{ Cronbach's a } & .676 & .802 & .759 & .869 & .869 \\
\hline
\end{tabular}


Table 3: Convergent and Discriminant Validity

\begin{tabular}{|l|c|c|c|c|c|c|}
\hline & AVE & LD & LI & LO & CL & CE \\
\hline $\begin{array}{l}\text { Learning-by-Doing } \\
\text { Support (LD) }\end{array}$ & 0.452 & $\mathbf{0 . 6 7 2}$ & & & & \\
\hline $\begin{array}{l}\text { Learning-by-investment } \\
\text { Support (LI) }\end{array}$ & 0.486 & $0.329^{* *}$ & $\mathbf{0 . 6 9 7}$ & & & \\
\hline $\begin{array}{l}\text { Learning-from-others } \\
\text { Support (LO) }\end{array}$ & 0.440 & $0.505^{* *}$ & $0.503^{* *}$ & $\mathbf{0 . 6 6 3}$ & & \\
\hline Customer Learning (CL) & 0.652 & $0.416^{* *}$ & $0.343^{* *}$ & $0.292^{* *}$ & $\mathbf{0 . 8 0 7}$ & \\
\hline $\begin{array}{l}\text { Customer Experience } \\
\text { (CE) }\end{array}$ & 0.778 & 0.157 & 0.010 & 0.091 & $0.192^{*}$ & $\mathbf{0 . 8 8 2}$ \\
\hline
\end{tabular}

Note: The diagonal values represent the values of square root of AVE.

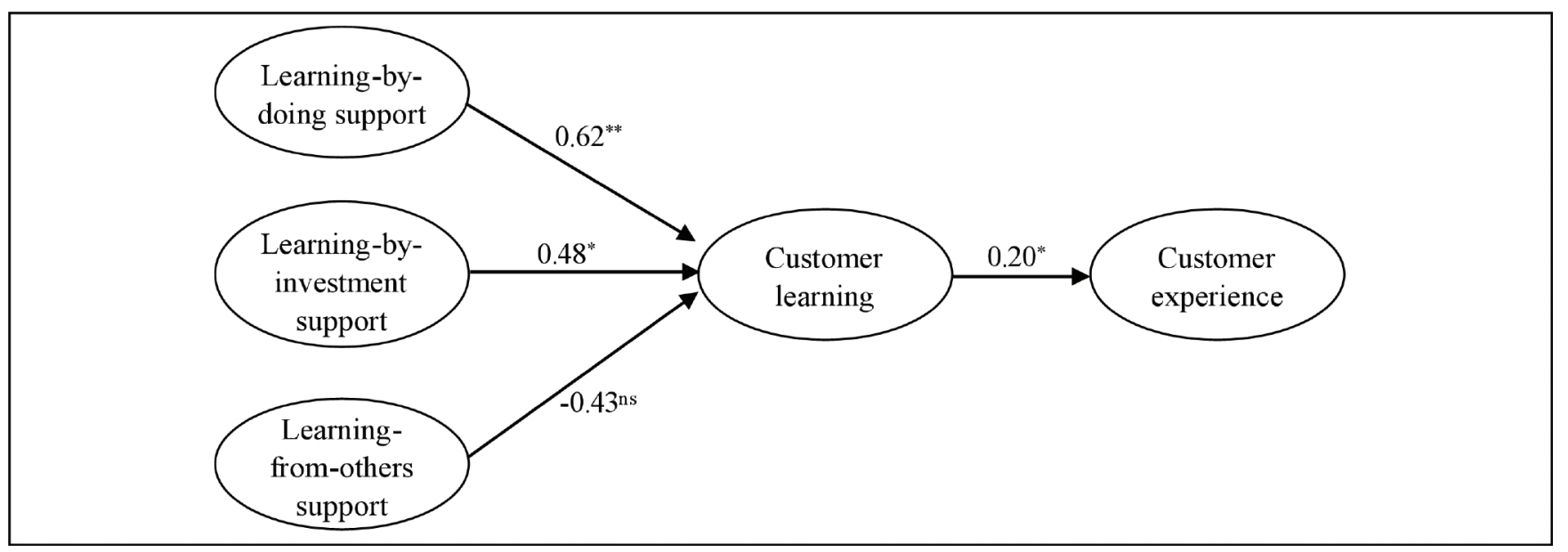

Figure 3: The Results of Structural Model Test

\section{Results of Structural Model Test}

To assess the structural model, we used AMOS version 16.0. The results are shown in Figure 3.

The estimated model has a normed chi-square (chisquare/d.f.) of 1.27, which is below the recommended threshold of 3 (Gefen, Karahanna, \& Straub, 2003). The values of Goodness of Fit Index and Adjusted GFI are 0.892 and 0.853 , respectively. Although they are slightly lower than the cut-off value 0.9 at sample size greater than 200, considering the sample size of 139 in this study, it is acceptable (Lee, 1990). The value of normed Fit Index, 0.87 , is also close to the cut-off value 0.9 . The root mean squared residual is 0.052 , which is close to the cut-off 0.05 (Lee, 1990).

The fit indices we discussed so far are affected by the sample size. To investigate the model fit more closely, we checked additional indices such as Non-Normed Fit Index, Comparative Fit Index, and Root Mean Square Error of Approximation which are less affected by sample size if it is greater than 100 (Lee, 2000). The values of both NonNormed Fit Index and Comparative Fit Index are 0.961 and 0.968, respectively that exceed the cut-off 0.9 . The Root Mean Square Error of Approximation is 0.045 which is less than the cut-off 0.05 . In sum, these fit indices provide support for model fit.

The results of the structural model test show that customer learning has a statistically significant impact on customer experience and among all types of support for the learning processes, support for learning-by-doing and for learning-by-investment have a statistically significant impact on customer learning. However, support for learning-fromother does not appear to have a significant effect on customer learning. Table 4 shows the results of the hypothesis test. 
Table 4: Results of Hypothesis Test

\begin{tabular}{|l|l|c|c|c|c|}
\hline Hypothesis & \multicolumn{1}{|c|}{ Path } & $\begin{array}{c}\text { Path } \\
\text { Coefficient }\end{array}$ & $\begin{array}{c}\text { Standard } \\
\text { Error }\end{array}$ & t Value & Support \\
\hline H1 & Customer Learning $\rightarrow$ Customer Experience & 0.196 & 0.066 & $2.019^{*}$ & Yes \\
\hline H2a & Learning-by-Doing $\rightarrow$ Customer Learning & 0.617 & 0.291 & $2.628^{* *}$ & Yes \\
\hline H2b & Learning-by-Investment $\rightarrow$ Customer Learning & 0.476 & 0.309 & $2.233^{*}$ & Yes \\
\hline H2c & Learning-from-Others $\rightarrow$ Customer Learning & -0.429 & 0.308 & -1.451 & No \\
\hline
\end{tabular}

Note: ${ }^{*} p<0.05,{ }^{* *} p<0.01,{ }^{* * *} p<0.001$.

\section{Conclusion and Limitations}

In this study, we propose a model to investigate the impact of support for learning processes on customer learning which is in turn hypothesized to influence customer experience in the context of knowledge of products and services. The results of the analysis lend partial support to the proposed model.

\subsection{Conclusion}

The results show that customer experience is positively affected by customer learning. Among the kinds of support for the three learning processes as derived from Ryu et al. (2005), support for learning-by doing and learning-by-investment processes was found to positively affect customer learning. That is, if a service provider effectively supports the learning processes for customers, to study relevant materials and to test or experiment with, or actually use a service or product before and/or after they purchase it, customers can acquire knowledge pertinent to the use of the service and product. Interestingly, the support for the learning-from-others process appears not to have a significant effect on customer learning, which is contrary to the results of past studies (Bickart \& Schindler, 2001). This may happen because there might be a sequence in the process or because Apple iPods and iTunes service does not allow customers to share their music files with other customers within their community. If the learningfrom-others process affects the other two processes of learning-by-doing and learning-by-investment in the context of the Apple iPod music service, its direct effect on customer learning might not be significant. This issue is subject to further research, because designing support for the learning processes in a proper manner may reduce the cost incurred by companies in investing in building customer communities, which leads to better customer experience with a service.

\subsection{Theoretical Implications}

This study contributes to the literature by identifying different types of support for different kinds of customer learning processes and by empirically testing the impact of the support for the process on customer learning, and in turn, its impact on customer experience. Past studies on service and service innovation emphasize the importance of customer orientation and customer learning in providing better services to customers. However, to the best of our knowledge, there is little research that empirically examines the relationship. This study will provide a basis for future research on customer learning which is critical for the successful provision of knowledge on goods and services.

\subsection{Practical Implications}

This study provides some practical value for companies. Based on the customer learning processes identified by this study and the results found in the study, companies can design support for customer learning processes. The results of this study at least show that if a service provider effectively supports the processes of learning-by-doing and learning-byinvestment through which customers are allowed to study relevant materials and test or experiment with, or actually use a service or product before and/or after they purchase it, customers can acquire knowledge pertinent to the use of the service and product, which, in turn, increases customer loyalty and helps its bottom line. As in the case of Apple's concierge, companies can improve customers' learning-bydoing by selling product experience rather than selling itself to customers. In addition, companies should tell their customers what they can do with their products. Companies also need to provide their customers with a variety of ways to use their products through online media channels such as YouTube and SNSs (Social Networking Services), so that customers can learn whenever and wherever they want. However, at this moment, companies need to exercise caution in developing customer communities when they design support for customer learning, because its impact on customer learning is not clear.

\subsection{Limitations}

This study is not free from limitations. Future research needs to develop more sets of valid measurement items, considering this study's relatively low item loadings and AVEs, which necessitates further validation. In addition, future studies may want to expand the sample frame to include a variety of user groups of knowledge on services and products. This study focused on a group of Apple iPod users which may limit the generalizability of the findings of this study. 


\section{References}

Alter, S. (2008). Service System fundamentals: work system, value chain, and life cycle. IBM Systems Journal, 47(1), 71-85.

Bickart, B., \& Schindler, R. M. (2001). Internet forums as influential sources of consumer information. Journal of Interactive Marketing, 15(3), 31-40.

Chae, S. I. (2004). Research Methodology for Social Science (3rd ed.). Seoul, Korea: B\&M Books.

Cohen, W. M., \& Levinthal, D. A. (1990). Absorptive capacity: A new perspective on learning and innovation. Administrative Science Quarterly, 35(1), 128-152.

Fornell, C., \& Larcker, D. F. (1981). Evaluating structural equation models with unobservable variables and measurement error. Journal of Marketing Research, 18(1), 39-50.

Gefen, D., Karahanna, E., \& Straub, D. W. (2003). Trust and TAM in online shopping: An integrated model. MIS Quarterly, 27(1), 51-90.

Gentile, C., Spiller, N., \& Noci, G. (2007). How to sustain the customer experience: An overview of experience components that co-create value with the customer. European Management Journal, 25(5), 395-410.

Glushko, R. J. (2008). Designing a service science discipline with discipline. IBM Systems Journal, 47(1), 15-27.

Gronroos, C. (1990). Relationship approach to marketing in service contexts: The marketing and organizational behavior interface. Journal of Business Research, 20(1), 3-11.

Hennig-Thurau, T., Gwinner, K. P., Walsh, G., \& Gremler, D. D. (2004). Electronic word-of-mouth via consumeropinion platforms: What motivates consumers to articulate themselves on the Internet? Journal of Interact Market, $18(1), 38-52$.

Hindasah, L., \& Nuryakin, N. (2020). The relationship between organizational capability, organizational learning and financial performance. Journal of Asian Finance Economics and Business, 7(8), 625-633. https://doi.org/10.13106/jafeb.2020. vol7.no8.625

Kim, Y. J., \& Nam, K. (2007). A theoretical framework for understanding service science and service innovation. Science and Technology Policy, 17(6), 69-83.

LaSalle, D., \& Britton, T. A. (2003). Priceless: Turning Ordinary Products into Extraordinary Experiences. Boston, MA: Harvard Business School Press.

Lee, S. M. (1990). Covariance Structure Analysis. Seoul, Korea: Sungwon Co.

Lee, S. M. (2000). Fundamentals of Factor Analysis. Seoul, Korea: Education and Science Co.

Lim, J. W. (1996). Marketing Research. Seoul, Korea: Bummoon Co.

Nam, K., Kim, Y. J., Nam, J. T., Pae, Y. W., \& Byun, H. S. (2008). Service science: Theory review and development of analytical framework. Information Systems Review, 10(1), 213-235.

Payne, A. F., Storbacka, F., \& Frow, P. (2008). Managing the co-creation of value. Journal of the Academy of Marketing Science, 36(1), 83-96.

Pine, B. J. (1993). Mass customizing products and services. Planning Review, 21(4), 6-55.

Pine, B. J., \& Gilmore, J. H. (1999). The Experience Economy: Work is Theatre and Every Business a Stage. Boston, MA: Harvard Business School Press.

Prahalad, C. K., \& Ramaswamy, V. (2000). Co-opting customer competence. Harvard Business Review, 78(1), 79-87.

Prahalad, C. K., \& Ramaswamy, V. (2003). The new frontier of experience innovation. MIT Sloan Management Review, 44(4), $12-18$.

Ramaswamy, V. (2006). Co-creating experiences of value with customers. SETLabs Briefings, 4(1), 25-36.

Richins, M. L., \& Root-Shaffer, T. (1988). The role of involvement and opinion leadership in consumer word-of-mouth: An implicit model made explicit. Advances in Consumer Research, 15(1), 32-36.

Rosenberg, N. (1983). Inside the Black Box: Technology and Economics. Cambridge, UK: Cambridge University Press.

Ryu, C., Kim, Y. J., Chaudhury, A., \& Rao, H. R. (2005). Knowledge acquisition via three learning processes: Learningby-investment, learning-by-doing, and learning-from-others. MIS Quarterly, 29(2), 245-278.

Shapiro, C., \& Varian, H. R. (1999). Information Rules: A Strategic Guide to the Network Economy, Boston, MA: Harvard Business School Press.

Shaw, C., \& Ivens, J. (2005). Building Great Customer Experiences. New York, NY: MacMillan.

Song, Y., Chang, W., \& Chang, J. (2018). The effective factors of professional learning: Study on accounting firms in Korea. Journal of Asian Finance Economics and Business, 5(2), 8194. https://doi.org/10.13106/jafeb.2018.vol5.no2.81

Vargo, S. L., \& Lusch, R. F. (2004). Evolving to a new dominant logic for marketing. Journal of Marketing, 68(1), 1-17.

Vargo, S. L., Lusch, R. F., \& Morgan, F. W. (2006). Historical perspectives on service-dominant logic. The Service-Dominant Logic of Marketing: Dialog, Debate and Directions. Armonk, NY: M.E. Sharpe.

Wang, D., \& Lam, K. C. K. (2019). Relationship between ambidexterity learning and innovation performance: The moderating effect of redundant resources. Journal of Asian Finance Economics and Business, 6(1), 205-215. http://doi. org/10.13106/jafeb.2019.vol6.no1.205

World Bank. (2018). World Development Indicators: Structure of Output. Retrieved March 9, 2019, from: http://wdi.worldbank. org/table/4.2\#. 